\title{
INFLUENCE OF ANTHROPOGENIC FACTORS ON THE ECOLOGY OF MELANOCORYPHA CALANDRA AND ALAUDA ARVENSIS IN DEPRESSIONS OF DNIPRO - MOLOCHNA
}

\author{
T. Starovoitova \\ Postgraduate student \\ Institute of Agroecology and Environmental Management of NAAS \\ (Kyiv, Ukraine) \\ e-mail: starovoitovatetana@gmail.com; \\ ORCID: https://orcid.org/0000-0003-4243-1311
}

The research was carried out for 3 years in the steppe biotopes of the bottoms of the Ahaymany, Barnashivsky, Green, Big Chapelsk, and Small Chapelsk depressions of the Dnipro - Molochna interfluve. Based on visual inspection and processing of space images, the degree of anthropogenic transformation of these ecosystems is analyzed. The highest percentage of plowing is characteristic of the Ahaymany depression, which occurred in the last 10 years. Among the factors that significantly affect the nesting birds of the steppe complex are also the continuous low mowing of grass (Green depression) and overgrazing of livestock - Small Chapelsk depression.

The nesting density of background steppe species was determined, the highest density of Alauda arvensis in different years is characteristic of Ahaymany $\left(245,2\right.$ pairs $\left./ \mathrm{km}^{2}\right)$ and Barnashivsky depression $\left(211,2\right.$ pairs $\left./ \mathrm{km}^{2}\right)$, and Melanocorypha calandra - for the Big Chapelsk depression $\left(140,1\right.$ pairs $\left./ \mathrm{km}^{2}\right)$. Stable is only the territory of the Big Chapelsk depression the protected regime under moderate grazing load of wild ungulates. A positive correlation was established between the values of steppe habitat area and Alauda arvensis nesting in the Ahaymany, Barnashivsky, Small Chapelsk, and Green depressions and, accordingly, a negative dependence for Melanocorypha calandra.

Keywords: ornithocomplex, Passeriformes, anthropogenic transformation, biodiversity, agrolandscape.

\section{INTRODUCTION}

In recent decades, the southern steppe region of Ukraine has again undergone significant changes, then the activation, then the decline of human impact on the remnants of natural ecosystems. Natural processes in the southern steppes, which have formed the modern fertility potential of the agroecosystems, are entirely disrupted. First of all, this is accompanied by the loss of quantitative and qualitative characteristics of species biodiversity, which has shaped the mechanisms of sustainable functioning over the centuries. For species diversity that is not used by humans, leaving only those areas that its characteristics are unsuitable for intensive agricultural production. One of such territories is depressions in the interfluve of the Dnipro - Molochna. And its largest depression ecosystems are included in the objects of the Emerald Network [1-4].

At the same time, these remnants of natural ecosystems are significantly affected by exogenous and endogenous processes, most of which are again associated with human activities. In particular, complete plowing of catchment basins, over-regulation of beams that filled the bottoms of depressions, mowing of natural gras- ses, unbalanced grazing of ungulates, mowing of grasses, and in protected areas - a kind of reserve succession [5; 6]. Each of these factors has a mainly negative impact on ornithocomplexes, which can be traced in the number of species, density, and biomass.

The aim of the work is to establish changes in the ecology of two background steppe bird species in the depression ecosystems of the Dnipro Molochna interfluve under the influence of anthropogenic transformation.

\section{ANALYSIS OF THE LAST RESEARCH AND PUBLICATIONS}

Birds of steppe and agro landscapes in the interfluve of the Dnipro - Molochna have repeatedly attracted the attention of researchers. The systematic composition of the avifauna is well studied. Relatively complete data on the ecology of species, their distribution in protected areas [7], agro landscapes have been published $[8 ; 9]$, and the authentic steppe [10;11]. Regional studies, mostly performed by scientists of the Azov-Black Sea Ornithological Station, Askania-Nova Biosphere Reserve, Melitopol State Pedagogical University, give a generalized de- 
scription of the avifauna of the region [12-15], or relate to individual depressive ecosystems, such as the Big Chapelsk depression [16-18], or individual species [19-21]. However, despite the study of birds in the region, under the influence of anthropogenic factors, there is an acceleration of changes in their ecology, which should track, analyze and take action to minimize the negative factors.

\section{MATERIALS AND RESEARCH METHODS}

To assess the state of ecotopes, their changes under the anthropogenic influence, materials obtained as a result of ground-based visual inspection and analysis of space images of the Sentinel-2 region were used. Studies of the population structure and lark numbers were conducted during 2018-2020 in the depression ecosystems of the Dnipro - Molochna interfluve. For this purpose, laid accounting transect with an area of 0.14 to $0.33 \mathrm{~km}^{2}$ were established. The area of the model plots was $2.14 \mathrm{~km}^{2}$. During the research period, we covered $63 \mathrm{~km}$ of walking accounting routes with different modes of nature use. The density of singing males, and behind them the estimated number of nesting pairs were determined using the route method with a fixed width of the accounting strip [22] - $100 \mathrm{~m}$ (50 $\mathrm{m}$ on both sides). The routes were located closer to the middle of the studied biotopes in order to exclude ecotone effects. Birds were recorded during the nesting period in the morning and before sunset (April to June). The analysis included observations of two background species of larks: Melanocorypha calandra Linnaeus, 1766, and Alauda arvensis Linnaeus, 1758. Due to the high ecological valence of species, their characteristics are suitable for comparison in biocenoses of varying degrees of disturbance. All singing males were registered, taking into account their species identity. The calculation of the density of nesting pairs was performed according to formula 1 [23]:

$$
D=\frac{n}{M W},
$$

where $n$ - the total number of males detected on the accounting route; $M$ - the length of the accounting route; $W$ - the width of the accounting route.

To compare climatic indicators, the data of the meteorological station Askania-Nova were taken, which were processed by the program Microsoft Excel.

\section{RESULTS AND DISCUSSION}

Dynamics of changes in depressive ecosystems. The research was conduct in the years that have similar climatic conditions (Fig. 1). At the beginning of the nesting period in 2018 (April), there was almost no rain $(2.7 \mathrm{~mm}-9.6 \%$ of normal), which did not stimulate the active development of steppe vegetation. The beginning of the nesting period in 2019 (April) was rainy (38.9 mm - $138.9 \%$ of normal). May and June were noted the somewhat average level of rainfall and amounted to $42.4 \mathrm{~mm}$ (111.5\% of normal) and $14.1 \mathrm{~mm}$ (30.6\% of normal). In April 2020, there was almost no rain $(7.5 \mathrm{~mm}-26.7 \%$ of normal). May and June were rainier during this period amount of precipitation were $42.4 \mathrm{~mm}$ and $59.3 \mathrm{~mm}$ 111.5 and $128.9 \%$ of normal. The indicators of the average decade temperature did not differ significantly.

It should be noted that the process of plowing fallows, depressions, coastal strips, despite the numerous recommendations of nature conservationists, in recent years is gaining momentum
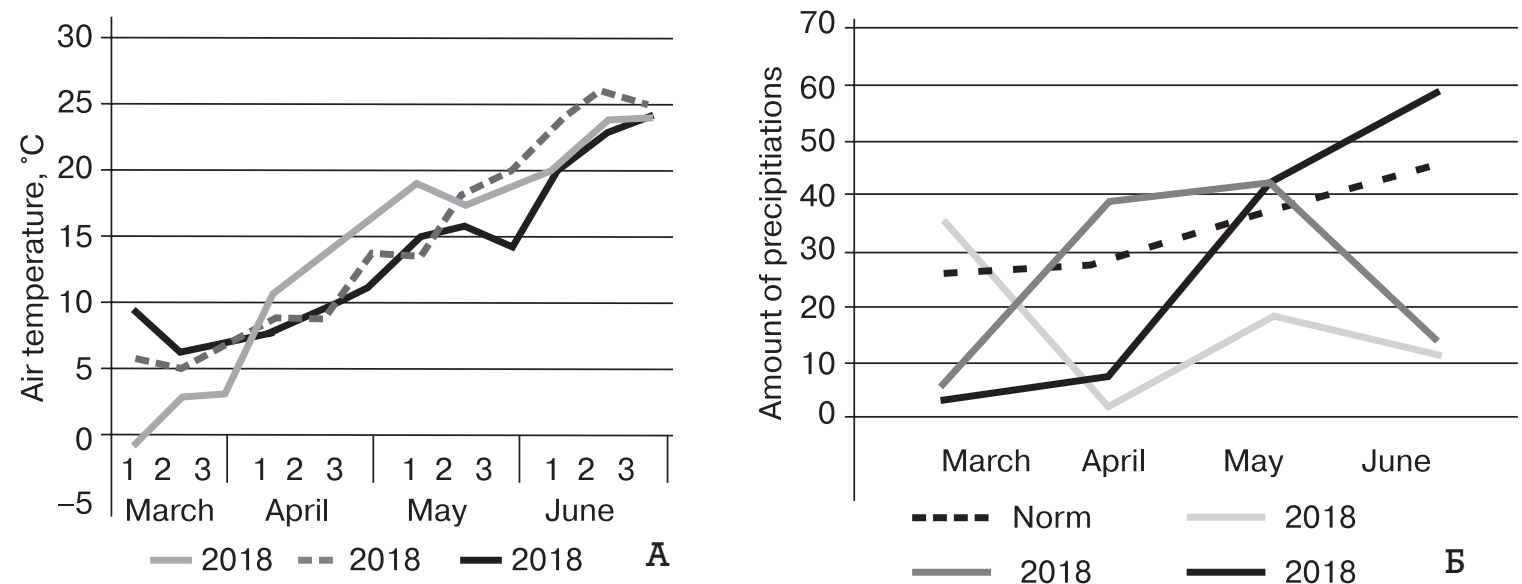

Fig. 1. Seasonal dynamics of air temperature $(A)$ and precipitation $(B)$ during the reproductive period of larks 2018-2020.

Source: developed by the author based on data from the Askania-Nova meteorological station. 
again. Steppe biotope as of 2020 remained only partially at the bottom of the depressions. Thus, in the largest of the depressions - Ahaymany natural ecosystems now occupy no more than $12.8 \%$ of the total area of the depression (Table 1). Part of the territory of its bottom is annually mowed for haymaking. At the same time, according to our observations, at a mowing height of 11$15 \mathrm{~cm}$, larks continue to hold territory, and renest, which is due to the presence of conditions for the hidden location of nests and forage base. The upland and slopes of this depression are completely plowed, farming carried out, where only single pairs of field larks are observing on nesting.

Barnashivskyy depression situated near the Biosphere Reserve «Askania Nova». Has an insignificant difference in height between the bottom and the upland of the catchment area. The slopes and half of the bottom of the depressions are plowed. Every year the area of plowed areas increases. For 2020, 27.8\% of the total area is in the natural state, where hay is also harvested annually, with a height of $11-15 \mathrm{~cm}$.

The Green depression also transformed. It is cut by the main and drainage channels of the Kakhovka irrigation system. In the middle of the depression, there is a large 200 -hectare storage pond on the slopes and the upland plowed. Steppe biotopes remained at the bottom of the depression their area during the study period continued to decrease - from 36.8 to $28 \%$. Steppe areas are used for haymaking. In contrast to the above-mention depressions, mowing with grass $(3-5 \mathrm{~cm})$ is very noticeable here, which causes mechanical damage to the nests and leaves almost no block forest planting for re-nesting.
Small Chapelsk depression is subject to extensive economic use by grazing livestock, due to which in its south-eastern part there is overgrazing. A small part of the territory is not mowed every year, damaging the nests of birds. Unlike previous depressions, steppe areas are reduced due to littering with waste from livestock farms $6 \%$ of the total area.

The area and load of steppe biotopes of the Big Chapelsk depression, which is a part of the protected area of the Askania-Nova Biosphere Reserve, is stable. At the same time, a significant number of wild ungulates, which devour the green mass and cause its regrowth, and the real protected regime create stable conditions for the stay of birds of different ecological groups, including larks.

Dynamics of nesting density of larks. A comparative analysis of the results of bird counts in Big Chapelsk, Ahaymany, Barnashivskyi, Green, and Small Chapelsk depressions revealed a significant difference in the density of nesting pairs of Alauda arvensis and Melanocorypha calandra. Thus, the highest density of Alauda arvensis in general in different years is characteristic of the Ahaymany (245.2 pairs $/ \mathrm{km}^{2}$ ) and Barnashivskyi depression (211.2 pairs $/ \mathrm{km}^{2}$ ), the lowest — of the Big Chapelsk depression (50.1 pairs $/ \mathrm{km}^{2}$ ), and the Small Chapelsk depression (60.0 pairs $\left./ \mathrm{km}^{2}\right)$. At the same time, the highest density of Melanocorypha calandra (140.1 pairs $/ \mathrm{km}^{2}$ ) is observed in Big Chapelsk, and the lowest density is typical for the Green depression - 13.9 pairs $/ \mathrm{km}^{2}$ (Table 2). Estimation of dynamics for a short period of research is conditional, but even during this time, the general tendency of change of density of nesting of species is already traced.

The area of steppe biotopes of the studied depression ecosystems, their change during 2018-2020

\begin{tabular}{|c|c|c|c|c|c|c|c|c|c|c|c|}
\hline & \multirow[t]{2}{*}{ 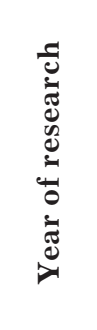 } & \multicolumn{2}{|c|}{ 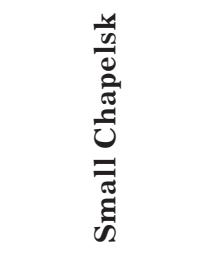 } & \multicolumn{2}{|c|}{ 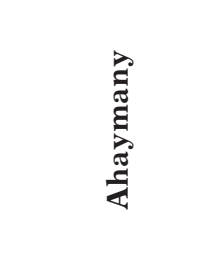 } & \multicolumn{2}{|c|}{ 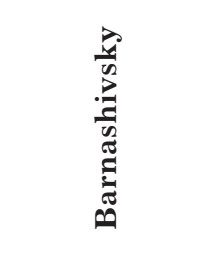 } & \multicolumn{2}{|c|}{ 造 } & \multicolumn{2}{|c|}{ 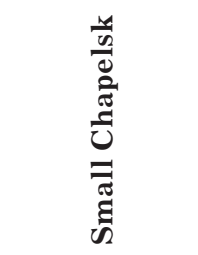 } \\
\hline & & $\kappa_{M^{2}}$ & $\%$ & $\mathbf{K M}^{2}$ & $\%$ & $\mathbf{K M}^{2}$ & $\%$ & $K \mathbf{M}^{2}$ & $\%$ & $\kappa \mathbf{M}^{2}$ & $\%$ \\
\hline $\begin{array}{l}\text { Depression } \\
\text { area }\end{array}$ & & 44,0 & 100 & 120,0 & 100 & 16,0 & 100 & 49,0 & 100 & 27,0 & 100 \\
\hline \multirow{3}{*}{$\begin{array}{l}\text { of them: } \\
\text { steppe } \\
\text { biotopes }\end{array}$} & 2018 & 26,0 & 59,1 & 73,5 & 61,3 & 8,1 & 50,6 & 18,1 & 36,8 & 13,8 & 51,1 \\
\hline & 2019 & 26,0 & 59,1 & 47,7 & 39,8 & 6,3 & 39,6 & 15,2 & 31,0 & 9,5 & 35,2 \\
\hline & 2020 & 26,0 & 59,1 & 15,6 & 12,8 & 4,5 & 27,8 & 13,7 & 28,0 & 8,7 & 32,2 \\
\hline
\end{tabular}

Source: developed by the author. 
The results of accounting Alauda arvensis and Melanocorypha calandra in depression ecosystems of the Dnipro - Molochna interfluve in 2018-2020 (nesting pairs per $1 \mathrm{~km}^{2}$ )

\begin{tabular}{|c|c|c|c|c|c|c|}
\hline \multirow[b]{2}{*}{ Specie } & \multirow[b]{2}{*}{ Year } & \multicolumn{5}{|c|}{ Depressions } \\
\hline & & 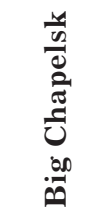 & 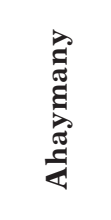 & 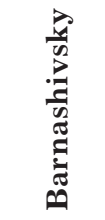 & 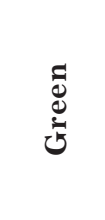 & 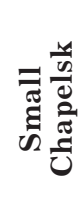 \\
\hline \multirow{4}{*}{ Alauda arvensis } & 2018 & 32,5 & 182,0 & 176,4 & 88,0 & 25,0 \\
\hline & 2019 & 62,0 & 265,2 & 201,8 & 91,2 & 75,0 \\
\hline & 2020 & 56,0 & 288,5 & 255,3 & 120,0 & 80,0 \\
\hline & $\begin{array}{l}\text { Average } \\
\text { value }\end{array}$ & 50,1 & 245,2 & 211,2 & 99,7 & 60,0 \\
\hline \multirow{4}{*}{$\begin{array}{l}\text { Melanocorypha } \\
\text { calandra }\end{array}$} & 2018 & 106,4 & 54,8 & 116,7 & 20,0 & 63,0 \\
\hline & 2019 & 160,0 & 49,0 & 55,2 & 11,6 & 5,0 \\
\hline & 2020 & 154,0 & 33,5 & 35,0 & 10,0 & 5,0 \\
\hline & $\begin{array}{l}\text { Average } \\
\text { value }\end{array}$ & 140,1 & 45,8 & 69,0 & 13,9 & 24,3 \\
\hline
\end{tabular}

Source: developed by the author.

Table 3

The impact of changes in the area of steppe biotopes areas on the number of nesting pairs

\begin{tabular}{|l|c|c|c|c|}
\hline \multirow{2}{*}{\multicolumn{2}{c|}{ Specie }} & \multicolumn{4}{c|}{ Depressions } \\
\cline { 2 - 5 } & Ahaymany & Barnashivsky & Green & Small Chapelsk \\
\hline \hline Alauda arvensis & $-0,93$ & $-0,98$ & $-0,82$ & $-0,90$ \\
\hline Melanocorypha calandra & 0,98 & 0,95 & 0,98 & 0,98 \\
\hline
\end{tabular}

Source: developed by the author.

In particular, for four depressions, an increase in the number of Alauda arvensis and a relatively stable density in the Big Chapelsk depression were found. Over the years of observations, the population dynamics of Melanocorypha calandra is positive only for Big Chapelsk, in other depressions the number decreases.

The impact of changes in the area of steppe biotopes areas on the number of nesting pairs of larks was determined by correlation analysis. A positive correlation has been established between the values of the steppe biotopes area and nesting Alauda arvensis in Ahaymany, Barnashivsky, Small Chapelsk, and Green depressions. And, accordingly, a negative dependence for Melanocorypha calandra (Table 3 ).

The revealed dependence of the dynamics of lark density in key areas is probably explained by the biological characteristics of species as Alauda arvensis is a more ecologically plastic species it settles in semi-deserts, agro-landscapes, beams with meadow, and steppe vegetation $[9 ; 10]$. Probably, the transformation of steppe biotopes leads to the displacement of authentic steppe species of Sparrows, thus freeing up an ecological niche for Alauda arvensis.

In turn, Melanocorypha calandra is found for nesting in all areas where there are even small areas of steppe vegetation (at least $0.1 \mathrm{~km} 2$ ). At the same time, cluster groupings of a kind are trace from 3 to 5-6 pairs. But the reduction of virgin areas in both depressions ecosystems and adjacent areas leads to a sharp decrease in the number of nesting groups of this species with subsequent possible extinction.

\section{CONCLUSIONS}

Depression ecosystems of the Dnipro - Molochna interfluve, which are the most attractive biotopes for larks nesting Alauda arvensis and 
Melanocorypha calandra, are significantly affected by anthropogenic factors.

The highest intensity of plowing in the last 5 years concerns the Ahaymany depression. Only Big Chapelsk with a protected regime under pasture load is stable.

The highest density Alauda arvensis is characteristic of the Ahaymany (245.2 pairs $/ \mathrm{km}^{2}$ ) and Barnashivsky (211.2 pairs $/ \mathrm{km}^{2}$ ) depressions, and Melanocorypha calandra - for the Big Chapelsk depression (140.1 pairs $/ \mathrm{km}^{2}$ ).

A positive relationship was found between the values of steppe habitat area and nesting Alauda arvensis and, accordingly, a negative dependence for Melanocorypha calandra. According to the data obtained, the most favorable for Melanocorypha calandra are steppe biotopes with a moderate level of a load of wild ungulates, and for Alauda arvensis - moderately mowed steppe areas.

\section{REFERENCES}

1. Shapoval, V.V., Starovoitova, T.V. \& Marushhak, O.Ju. (2019). Aghajmansjkyj pid [Ahaymany Depression]. Terytoriji, shho proponujutjsja do vkljuchennja u merezhu Emeraljd (Smaraghdovu merezhu) Ukrajiny ("tinjovyj spysok», chastyna 2) - Territories proposed for inclusion in the Emerald (Emerald Network) network of Ukraine ("shadow list», part 2). 166-169 [in Ukrainian].

2. Shapoval, V.V., Starovoitova, T.V. \& Marushhak, O. Ju. (2019). Barnashivsjkyj pid [Barnashivsky Depression]. Terytoriji, shho proponujutjsja do vkljuchennja u merezhu Emeraljd (Smaraghdovu merezhu) Ukrajiny ("tinjovyj spysok», chastyna 2) - Territories proposed for inclusion in the Emerald (Emerald Network) network of Ukraine ("shadow list», part 2). 170-172 [in Ukrainian].

3. Shapoval, V.V., Starovoitova, T.V. \& Marushhak, O.Ju. (2019). Zelenyj pid [Green Depression]. Terytoriji, shho proponujutjsja do vkljuchennja u merezhu Emeraljd (Smaraghdovu merezhu) Ukrajiny ("tinjovyj spysok», chastyna 2) - Territories proposed for inclusion in the Emerald (Emerald Network) network of Ukraine ( «shadow list», part 2). 179-181 [in Ukrainian].

4. Shapoval, V.V., Starovoitova, T.V. \& Marushhak, O.Ju. (2019). Malyj Chapeljsjkyj pid [Small Chapelsk Depression]. Terytoriji, shho proponujutjsja do vkljuchennja u merezhu Emeraljd (Smaraghdovu merezhu) Ukrajiny ("tinjovyj spysok», chastyna 2) - Territories proposed for inclusion in the Emerald (Emerald Network) network of Ukraine («shadow list», part 2). 186-188 [in Ukrainian].

5. Shapoval, V.V. (2007). Synantropnyj element flory askanijsjkogho stepu: struktura ta dynamika u konteksti rezervatnoji ekspozyciji terytoriji [Synanthropic element of the flora of the Askanian steppe: structure and dynamics in the context of the reserve exposition of the territory]. Zapovidni stepy Ukrajiny. Suchasnyj stan ta perspektyvy jikh zberezhennja-Reserved steppes of Ukraine. Current state and prospects for their preservation, 115-119 [in Ukrainian].

6. Tkachenko, V.S. \& Shapoval, V.V. (2010). Sukcesiji fitosystem diljanky «Pivnichna» novoaskanijsjkogho zapovidnogho stepu u drughij polovyni XX i na pochatku XXI st. [Successions of phytosystems of the «Northern» area of the Novoaskanian protected steppe in the second half of the XX and the beginning of the XXI century]. Visti Biosfernoho zapovidnyka "Askaniia-Nova" - News Biosphere Reserve "Askania-Nova», 12, 21-32 [in Ukrainian].

7. Lystopadsky, M.A. \& Gofman, O.P. (2017) Osobly`vosti ekologiyi ta prostorovoyi struktury` naselennya zhajvoronka stepovogo (Melanocorypha calandra) v zapovidnomu stepu Askaniya-Nova [Features of ecology and spatial structure of the population of calandra lark (Melanocorypha calandra) in the protected steppe Askania-Nova.] Zapovidna sprava u Stepoviy zoni Ukrayiny - Protected area in the steppe zone of Ukraine, 3, 259-263 [in Ukrainian].

8. Kuzmenko, T.M. (2012). Bird Distribution in Biotopes of Open Agricultural Lands in Breeding Season. Vestnik zoologii, 46(1), 41-44 [in English].

9. Bolnykh, S.I. (2011). Nekotorye zakonomernosti formirovanija gnezdovogo naselenija polevogo zhavoronka (Alauda arvensis) na sel'skohozjajstvennyh zemljah Lipeckoj oblasti [Some conformities of formation of the nested population of the Alauda arvensis on the agricultural landscapes of Lipetsk region]. Vestnik TGPU - Tomsk State Pedagogical University Bulletin, 5 (107), 91-96 [in Russian].

10. Oparin M.L. et al. (2015). Dinamika struktury gnezdovogo naselenija zhavoronkov (Alaudidae, Aves) v polupustyne saratovskogo Zavolzh'ja [Structure dynamics of the breeding population of larks (Alaudidae, Aves) in a semidesert of the Saratov Trans-Volga region]. Povolzhskij jekologicheskij zhurnalPovolzhskiy Journal of Ecology, 3, 277-293 [in Russian].

11. Didem Ambarl, C. Can Bilgin. (2014). Effects of landscape, land use and vegetation on bird community composition and diversity in Inner Anatolian steppes. Agriculture, Ecosystems and Environment, 182, 37-46 [in English].

12. Andryushchenko, Yu.A., Chernichko, I.I., Kinda, V.V. \& Popenko, V.M. (2006). Rezultaty pervogo bolshogo ucheta zimuyushchikh ptits v zonalnykh landshaftakh yuga Ukrainy [Results of the first large census of wintering birds in zonal landscapes of South Ukraine] Branta - Branta, 9, 123-149. [in Ukrainian]. 
13. Andryushchenko, Yu.A., Diadicheva, E.A. \& Popenko, V.M. (2015). K kharakteristike vesennego naseleniya ptits sukhostepnoy podzony Ukrainy v predelakh mezhdurechya Dnepra i Molochnoy [To the characteristic of spring population of birds of the dry steppe subzone of Ukraine within the Dnipro and Molochna interfluve]. Berkut - Berkut, 24 (2), 77-86 [in Ukrainian].

14. Andryushchenko, Yu.O., et al. (2019). Current status of Anserinae wintering in Azov-Black Sea region of Ukraine. Vestnik Zoologii, 53 (4), 297-312 [in Ukrainian].

15. Koshelev, O.I., Koshelev \& V.O., Fedushko, M.P., Zhukov, O.V. (2019). Riznomanittja ughrupovanj ta indykatorni plejady ptakhiv pryrodnykhj antropoghenno transformovanykh landshaftiv Pivdnja ta Pivdennogho skhodu Ukrajiny. [The bird communities diversity and indicator groups of natural and anthropogenic landscapes of the South and South-east of Ukraine]. Agrology, 2 (4), 229-240 [in Ukrainian].

16. Havrielenko, V.S. (2011). Ptitsy «Krasnoy knigi Ukrainy»v ekosistemakh Biosfernogo zapovednika "Askaniya-Nova» [Birds of the Red Book of Ukraine in the ecosystems of the Biosphere Reserve "Askania-Nova»]. Ridkisni y znykaiuchi ptakhy Pivnichno-Zakhidnoho Prychornomoria: zbirka naukovykh prats - Rare and endangered birds of the North-Western Black Sea coast: a collection of scientific works, 18-25 [in Ukrainian].

17. Havrylenko, V.S. \& Mezinov, O.S. (2013). Rol Velykoho Chapelskoho podu v zberezhenni bioriznomanittia navkolovodnykh ptakhiv Dniprovsko-Molochnianskoho mezhyrichchia [The role of the Great Chapelsky depression in the conservation of biodiversity of aquatic birds of the Dnipro-Molochnya interfluve]. Ekolohiia vodno-bolotnykh uhid $i$ torfovyshch (zbirnyk naukovykh statei) - Ecology of wetlands and peatland, 35-40 [in Ukrainian].

18. Havrylenko, V.S. \& Lystopadsky, M.A. (2016). Transformatsiia ornitokompleksiv pryrodnoho yadra i sumizhnykh terytorii Biosfernoho zapovidnyka «Askaniia-Nova» [Transformation of natural ornithocomplexes of the natural core area and adjacent territories to the Biosphere reserve "Askania-Nova»]. Visti Biosfernoho zapovidnyka "Askaniia-Nova» - News Biosphere Reserve "Askania-Nova», 18, 98-115 [in Ukrainian].

19. Havrylenko, V.S., Lystopadsky, M.A., Mezinov, O.S. \& Chegorka, P.P. (2013). Novi znakhidky ridkisnykh vydiv ptakhiv na terytorii Biosfernoho zapovidnyka «Askaniia-Nova» ta v yoho rehioni [New records of rare species of birds in Biosphere Reserve "Askania-Nova» and in its region]. Visti Biosfernoho zapovidnyka "Askaniia-Nova» - News Biosphere Reserve "Askania-Nova», 15, 267-269 [in Ukrainian].

20. Havrylenko, V.S. \& Starovoitova, T.V. (2018). Osobennosti vesenney migratsii serogo zhuravlya Grus grus (Linnaeus, 1758) cherez Biosfernyy zapovednik «Askaniya-Nova» i sopredelnye territorii v 2018 godu. [Features of the spring migration of the Eurasian Crane through Askania-Nova Biosphere Reserve and adjacent areas in 2018]. Informatsionnyy byulleten RGZh Yevrazii - Newsletter of the Crane Working Group of Eurasia, 14, 32-35 [in Russian].

21. Havrylenko, V.S. \& Starovoitova, T.V. (2020). Pody mezhyrichchya Dnipro - Molochna yak vazhlyvi oseredky zberezhennya ptakhiv Chervonoyi Knyhy Ukrayiny. [Depressions of Dnipro - Molochna interfluves as important centres of birds' conservation of the Red book of Ukraine]. Ahroekolohichnyy zhurnal-Agroecological journal, 3, 13-25 [in Ukrainian].

22. Bibbi, K., Dzhons, M. \& Marsden, S. (2000). Metody polevyh jekspedicionnyh issledovanij. Issledovanija i uchety ptic. [Field research methods. Research and counts of birds]. Moscow [in Russian].

23. Ravkin, E.S. \& Chelincev, N.G. (1990). Metodicheskie rekomendacii po kompleksnomu marshrutnomu uchetu ptic [Methodical recommendations for integrated route counting of birds]. Moscow [in Russian].

\title{
ВПЛИВ АНТРОПОГЕННИХ ФАКТОРІВ НА ЕКОЛОГІЮ MELANOCOR YPHA CALANDRA TA ALAUDA ARVENSIS У ПОДОВИХ ЕКОСИСТЕМАХ МЕЖИРІЧЧЯ ДНІПРО-МОЛОЧНА
}

\author{
Т.В. Старовойтова \\ аспірантка \\ Інститут агроекології і природокористування НАAН (м. Київ, Україна) \\ e-mail: starovoitovatetana@gmail.com; \\ ORCID: https: //orcid.org/0000-0003-4243-1311
}

Дослідження проводилися впродовж 3-х років у степових біотопах днищ Агаймансъкого, Барнашівсъкого, Зеленого, Великого Чапельсъкого та Малого Чапелъсъкого подах межиріччя Дніпро Молочна. На основі візуального огляду та обробки космічних знімків проаналізовано ступінъ антропогенної трансборлаиї ији екосистем. Найвищий відсоток розорювання, шо сталося за останні 10 років, характерний для Агайлансъкого поду. Серед чинників, шоо суттєво впливають на гніздування птахів степового комплексу, є також суијльне низъке скошування травостою (Зелений під) та перевипас свійсъкою худобою (Малий Чапелъсъкий під).

Визначено щільність гніздування фонових степових видів: найвища щільність Alauda arvensis в

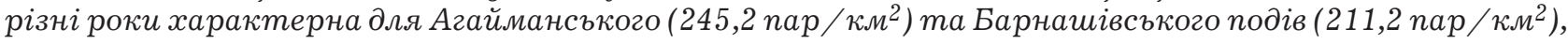


Influence of anthropogenic factors on the ecology of Melanocorypha calandra

and Alauda arvensis in depressions of Dnipro - Molochna

a Melanocorypha calandra - для Великого Чапельсъкого поду (140,1 пар/кл $\left.{ }^{2}\right)$. Стабільною є тільки територія Великого Чапельсъкого поду з заповідним режимом під помірним пасовищним навантаженням дикими копитними тваринами. Встановлено позитивний кореляиійний зв'язок між значеннями плоші степових біотопів та гніздування Alauda arvensis в Агаймансъкому, Барнашівсъкому, Малому Чапельсъкому та Зеленому подах i, відповідно, негативну залежність для Мецапocorypha calandra.

Ключові слова: орнітокомплекс, Горобцеподібні, антропогенна трансбормація, біорізноманіття, агроландиабот.

\section{ЛITEPATУРA}

1. Агайманський під / Шаповал В.В., Старовойтова Т.В., Марущак О.Ю. Територї, що пропонуютъся до включення у мережу Елеральд (Смарагдову мережу) України («тінъовий список», частина 2): кол. авт., під ред. Борисенко К.А., Куземко А.А. 2019. С. 166-169.

2. Барнашівський під / Шаповал В.В., Старовойтова Т.В., Марущак О.Ю. Територї, шо пропонуютъся до включення у мережу Елеральд (Смарагдову мережу) України («тінъовий список», частина 2): кол. авт., кол. авт., під ред. Борисенко К.А., Куземко А.А. 2019. С. 170-172.

3. Зелений під / Шаповал В.В., Старовойтова Т.В., Марущак О.Ю. Територї, що пропонуються до включення у мережу Елеральд (Сларагдову мережу) Украӥни («тінъовий список», частина 2): кол. авт., під ред. Борисенко К.А., Куземко А.А. 2019. С. 179-181.

4. Малий Чапельський під / Шаповал В.В., Старовойтова Т.В., Марущак О.Ю. Територї, що пропонуються до включення у мережу Емеральд (Смарагдову мережу) України («тінъовий список», частина 2): кол. авт., під ред. Борисенко К.А., Куземко А.А. 2019. С. 186-188.

5. Шаповал В.В. Синантропний елемент флори асканійського степу: структура та динаміка у контексті резерватної експозиції території. Заповідні степи України. Сучасний стан та перспективи їх збереження. 2007. C. 115-119.

6. Ткаченко В.С., Шаповал В.В. Сукцесії фітосистем ділянки «Північна» новоасканійського заповідного степу у другій половині XX і на початку XXI ст. Bicmi Біосферного заповідника "Асканія-Нова». 2010. T. 12. С. $21-32$.

7. Листопадський М.А., Гофман О.П. Особливості екології та просторової структури населення жайворонка степового (Melanocorypha calandra) в заповідному степу Асканія-Нова. Заповідна справа у Cтеповій зоні України (до 90-річчя від створення Надморських заповідників). 2017. № 3. С. $259-263$.

8. Kuzmenko T.M. Bird Distribution in Biotopes of Open Agricultural Lands in Breeding Season. Vestnik zoologii. 2012. 46(1): e-41-e-44.

9. Больных С.И. Некоторые закономерности формирования гнездового населения полевого жаворонка (Alauda arvensis) на сельскохозяйственных землях Липецкой области. Вестник ТГПУ. 2011. Выпуск 5 (107). C. 91-96.

10. Опарин M.Л. и др. Динамика структуры гнездового населения жаворонков (Alaudidae, Aves) в полупустыне саратовского Заволжья. Поволжский экологический журнал. 2015. № 3. C. 277-293.

11. Didem Ambarl1, C. Can Bilgin. Effects of landscape, land use and vegetation on bird community composition and diversity in Inner Anatolian steppes. Agriculture, Ecosystems and Environment. 2014. (182). P. 37-46.

12. Андрющенко Ю.А. и др. Результаты первого большого учета зимующих птиц в зональных ландшафртах юга Украины. Бранта. 2006. Вып. 9. С. 123-149.

13. Андрющенко Ю.А., Дядичева Е.А., Попенко В.М. К характеристике весеннего населения птиц сухостепной подзоны Украины в пределах междуречья Днепра и Молочной. Беркут. 2015. № 24, вип 2. С. $77-86$.

14. Andryushchenko Yu.O., Gavrilenko V.S., Kostiushyn V.A., Kucherenko V.N., Mezinov A.S., Petrovich Z.O., Redinov K.A., Rusev I.T., Yakovlev M.V. Current status of Anserinae wintering in Azov-Black Sea region of Ukraine. Vestnik Zoologii. 2019. № 53 (4). P. 297-312.

15. Кошелев O.І., Кошелев В.О., Федюшко М.П., Жћков О.В. Різноманіття угруповань та індикаторні плеяди птахів природних й антропогенно трансформованих ландшафтів Півдня та Південного сходу України. Agrology. № 2 (4). 2019. C. 229-240.

16. Гавриленко В.С. Птицы «Красной книги Украины» в экосистемах Биосферного заповедника «Аскания-Нова». Рідкісні й зникаючі птахи Північно-Західного Причорномор'я: збірка наукових праць [за ред. Русєва I.T., Корзюкова А.І.]. Одеса, 2011. С. 18-25.

17. Гавриленко В.С. Мезінов О.С. Роль Великого Чапельського поду в збереженні біорізноманіття навколоводних птахів Дніпровсько-Молочнянського межиріччя. Екологія водно-болотних угідъ $i$ торбовищ (збірник наукових статей). Київ, 2013. С. 35-40.

18. Гавриленко В.С., Листопадський М.А. Трансформація орнітокомплексів природного ядра і суміжних територій Біосферного заповідника «Асканія-Нова». Вісті Біосфберного заповідника «Асканія-Нова». 2016. T. 18. C. $98-115$. 
19. Гавриленко В.С., Листопадський М.А., Мезінов О.С., Чегорка П.П. Нові знахідки рідкісних видів птахів на території Біосферного заповідника «Асканія-Нова» та в його регіоні. Bicmi Біосферного заповідника "Асканія-Нова». 2013. Т. 15. С. 267-269.

20. Гавриленко В.С., Старовойтова Т.В. Особенности весенней миграции серого журавля Grus grus (Linnaeus, 1758) через Биосферный заповедник «Аскания-Нова» и сопредельные территории в 2018 году. Информаиионный бюллетень РГЖ Евразии. Москва, 2018. № 1. С. 32-35.

21. Гавриленко В.С., Старовойтова Т.В. Поди межиріччя Дніпро-Молочна як важливі осередки збереження птахів Червоної Книги України. Агроекологічний журнал. 2020. № 3. С. 13-25.

22. Бибби К., Джонс М., Марсден С. Методы полевых экспедиционных исследований. Исследования и учеты птии. Москва, 2000. 186 с.

23. Равкин Е.С., Челинцев Н.Г. Методические рекомендации по комплексному маршрутному учету птиц. Москва, 1990. 36 с.

\section{ВІДОМОСТІ ПРО АВТОРА}

Старовойтова Тетяна Вікторівна, аспірантка, Інститут агроекології та природокористування НААН (вул. Метрологічна, 12, м. Київ, Україна, 03143; e-mail: starovoitovatetana@gmail.com; тел.: +380963654064; ORCID: https://orcid.org/0000-0003-4243-1311)

\section{HOBEHE}

\footnotetext{
$\mathrm{K}^{\mathrm{s}}$ абінет Міністрів України 21 квітня затвердив порядок проведення національної інвентаризації лісів, який дасть можливість отримати вичерпну інформацію про кількість і якість лісів в Україні.
} 